\title{
Proteomic Analysis of Hepatocellular Carcinoma Tissues With Encapsulation Shows Up-regulation of Leucine Aminopeptidase 3 and Phosphoenolpyruvate Carboxykinase 2
}

\author{
KEISUKE KUHARA ${ }^{1,2}$, TAKAO KITAGAWA ${ }^{1}$, BYRON BARON ${ }^{3}$, KAZUHIRO TOKUDA $^{4}$, \\ KAZUHIKO SAKAMOTO ${ }^{5}$, HIROAKI NAGANO ${ }^{5}$, KAZUYUKI NAKAMURA ${ }^{6}$, \\ MASANOBU KOBAYASHI ${ }^{1}$, HIROKI NAGAYASU $^{2}$ and YASUHIRO KURAMITSU ${ }^{1}$ \\ ${ }^{1}$ Advanced Research Promotion Centre, Health Sciences University of Hokkaido, Ishikari-Tobetsu, Japan; \\ ${ }^{2}$ Division of Oral and Maxillofacial Surgery, Department of Human Biology and Pathophysiology, \\ School of Dentistry, Health Sciences University of Hokkaido, Ishikari-Tobetsu, Japan, \\ ${ }^{3}$ Centre for Molecular Medicine and Biobanking, University of Malta, Msida, Malta; \\ ${ }^{4}$ Graduate School of Health and Welfare, Yamaguchi Prefectural University, Yamaguchi, Japan; \\ ${ }^{5}$ Department of Gastroenterological, Breast and Endocrine Surgery, \\ Yamaguchi University Graduate School of Medicine, Ube, Japan; \\ ${ }^{6}$ Centre of Clinical Laboratories in Tokuyama Medical Association Hospital, Shunan, Japan
}

\begin{abstract}
Background/Aim: Cancer is the most fatal disease worldwide whose most lethal characteristics are invasion and metastasis. Hepatocellular carcinoma (HCC) is one of the most fatal cancers worldwide. HCC often shows encapsulation, which is related to better prognosis. In this study, proteomic analysis of HCC tissues with and without encapsulation was performed, in order to elucidate the factors which play important roles in encapsulation. Materials and Methods: Five HCC tissues surrounded by a capsule and five HCC tissues which broke the capsule were obtained from patients diagnosed with HCC who underwent surgical liver resection. Protein samples from these tissues were separated by two-dimensional gel electrophoresis (2-DE), and the protein spots whose expression was different between encapsulated and non-encapsulated HCC tissues were identified through gel imaging analysis software. The selected protein spots were analyzed and identified by liquid chromatography-tandem mass spectrometry (LC-MS/MS).
\end{abstract}

This article is freely accessible online.

Correspondence to: Yasuhiro Kuramitsu, MD, Ph.D., Advanced Research Promotion Centre, Health Sciences University of Hokkaido, 1757 Kanazawa, Ishikari-Tobetsu, Hokkaido 061-0293, Japan. Tel: +81 133231630, Fax: +81 133231782, e-mail: climates@hoku-iryo-u.ac.jp

Key Words: HCC, proteomics, encapsulation, leucine aminopeptidase 3 , phosphoenolpyruvate carboxykinase mitochondrial.
Results: Two-DE analysis showed 14 spots whose expression was different between encapsulated and non-encapsulated HCC tissues. Of these, 9 were up-regulated and 5 were downregulated in HCC tissues without encapsulation. The validation by Western blot confirmed that leucine aminopeptidase 3 (LAP3) and phosphoenolpyruvate carboxykinase mitochondrial (PCK2) were up-regulated significantly in HCC tissues with a capsule, compared to HCC tissues that broke the capsule. Conclusion: These findings suggest that LAP3 and PCK2 could be factors responsible for the maintenance of encapsulation in HCC tissues.

Although multidisciplinary therapies such as surgery, radiation and chemotherapy have made progress in the treatment of cancer, the latter is still one of the leading causes of death in many countries. Many types of cancer show strong invasive and metastatic capability. Cancer metastasis is composed of a number of steps. In principle, cancer cells show epithelial-to-mesenchymal transition (EMT) and migrate into surrounding tissues in the course of degrading extracellular matrix from cancer primary tissues. After intravasation, the cancer cells move to distant organs. Then, cancer cells extravasate from blood vessels, and invade the parenchyma and infiltrate adjacent tissues. Lastly, the cancer cells establish a metastatic tumor tissue with a wealth of tumor vasculature (1).

So far, many types of anti-metastatic drugs, targeting multiple steps in the process of metastasis have been developed. Anti-matrix metalloproteinase (anti-MMP) drugs marimastat (2), prinomastat (3), BMS-275291, metastat (4) 


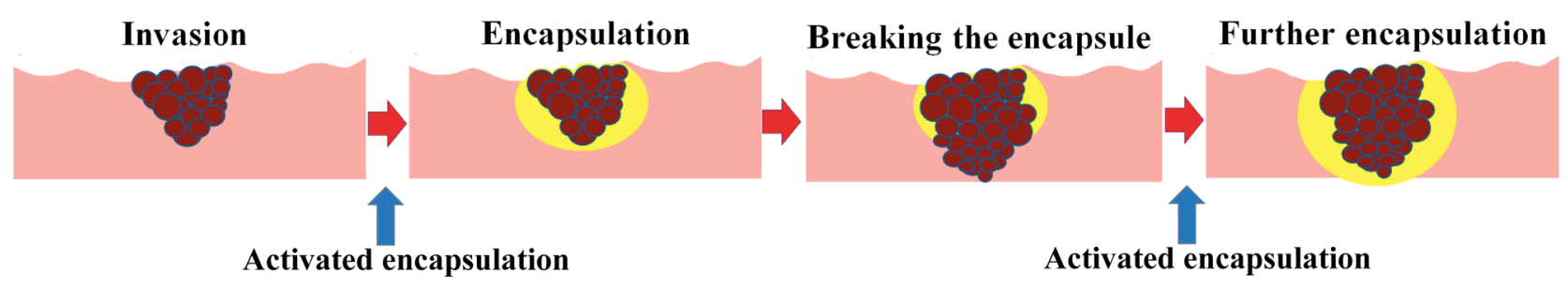

Figure 1. Cancer cells invade the surrounding tissue. Encapsulation against invading cancer cells is induced by the activated molecules which maintain the encapsulation. However, cancer cells can reinvade the surrounding tissue. The identified molecules are activated and induce the encapsulation for invading cancer cells repeatedly.

and neovastat (5) have been developed, while SU5416 and SU6668 are anti-angiogenesis drugs (6), and have been $t$ used in the phase II studies for several types of cancer. However, unfortunately all of these never yielded sufficient results, because any doctor does not choose them for the priority routine therapy for patients with advanced cancer (7).

In hepatocellular carcinoma (HCC), tissues are sometimes encapsulated with fibrous tissue (8). $\mathrm{Ng}$ et al. reported a pathologic study of 189 cases in which encapsulated tumors showed a much lower incidence of direct liver invasion $(p<0.0001)$ compared to non-encapsulated ones, and it was apparent that a lower tumor invasiveness contributed significantly to the better prognosis of encapsulated HCCs $(9,10)$. Some groups reported that myofibroblasts are the cellular source of capsular collagen $(11,12)$. However, the detailed molecular mechanisms of capsule formation are still unclear. It would be highly beneficial to elucidate the molecules which induce the capsule formation in HCC tissues, and apply these mechanisms to inhibit cancer invasion and metastasis. As stated above, the prognosis of patients with encapsulated HCC is much better than of HCC patients without encapsulation. The encapsulated HCC tissues show lower invasion and metastasis, but in the malignant progression process HCC cells break the capsule and start invasion and metastasis. Therefore, it is important to identify the molecules which play the essential roles in maintaining the encapsulation, and to therapeutically activate or induce the identified molecules to maintain the encapsulation (Figure 1).

The proteomic differential display method is a basic method to compare the protein expression profiles among different sample groups. The combinatorial technique of twodimensional gel electrophoresis (2-DE) and mass spectrometry (MS) have assumed a large role in proteomic differential display (13).

In this study, we compared the expression patterns of intracellular proteins in encapsulated and non-encapsulated HCC tissues by means of 2-DE, and identified proteins whose expression was different in these two groups by means of MS. The purpose of the present study was to identify molecules which may be responsible for the maintenance of encapsulation of HCC tissues.

\section{Materials and Methods}

Tumor samples. Five HCC tissues surrounded by a capsule and five HCC tissues with a broken capsule were obtained from patients diagnosed with HCC who underwent surgical liver resection at the Department of Surgery II, Yamaguchi University Hospital (Table I). None of the patients received any preoperative therapy. The study protocol was approved by the Institutional Review Board for Human Use of the Yamaguchi University School of Medicine and Health Sciences, University of Hokkaido. Written informed consent was obtained from all patients before surgery. The HCC tissue samples were treated by only K. S., S. H. and Y.K.

Sample preparation. HCC tissue samples were homogenized in lysis buffer $(50 \mathrm{mM}$ Tris- $\mathrm{HCl}, \mathrm{pH}$ 7.5, $165 \mathrm{mM}$ sodium chloride, $10 \mathrm{mM}$ sodium fluoride, $1 \mathrm{mM}$ sodium vanadate, $1 \mathrm{mM}$ PMSF, $10 \mathrm{mM}$ EDTA, $10 \mu \mathrm{g} / \mathrm{ml}$ aprotinin, $10 \mu \mathrm{g} / \mathrm{ml}$ leupeptin, and 1\% NP-40), and centrifuged at $15,000 \mathrm{~g}$ for $30 \mathrm{~min}$ at $4^{\circ} \mathrm{C}$. The supernatants were used as samples.

Two-dimensional gel electrophoresis. For two-dimensional gel electrophoresis, $80 \mu \mathrm{g}$ of protein was applied. Samples were mixed with $200 \mu \mathrm{l}$ of rehydration buffer ( $8 \mathrm{M}$ urea, $2 \%$ CHAPS, $0.01 \%$ bromophenol blue, $1.2 \%$ Destreak reagent (GE Healthcare, Buckinghamshire, UK) and 0.5\% IPG buffer (GE Healthcare) and loaded into the IPGphor strip holder (GE Healthcare). Isoelectric focusing (IEF) was performed using the following voltage program: rehydration for $10 \mathrm{~h}$ (no voltage), a stepwise increase from 0 to 500 $\mathrm{V}$ for $4 \mathrm{~h}, 500$ to $1,000 \mathrm{~V}$ for $1 \mathrm{~h}, 1,000$ to $8,000 \mathrm{~V}$ for $4 \mathrm{~h}$, a linear increase from $8,000 \mathrm{~V}$ for $20 \mathrm{~min}$, and a final phase of $500 \mathrm{~V}$ from 20,000 to $30,000 \mathrm{Vh}$. After IEF, SDS-polyacrylamide gel electrophoresis (SDS-PAGE) was performed on a precast polyacrylamide gel with a linear concentration gradient of 5-20\% (BIO RAD, Hercules, CA, USA), run at 200 V. After 2-DE, the gels were fixed with $40 \%$ ethanol and $10 \%$ acetic acid for $2 \mathrm{~h}$, and stained with Flamingo ${ }^{\mathrm{TM}}$ Fluorescent Gel Stain (BIO RAD) overnight (14).

Image analysis and spot selection. The protein spots on the gels were recorded using the ProEXPRESS 2D Proteomic Imaging System (PerkinElmer Inc., Waltham, MA, USA). Expression levels of the protein spots were quantified with Progenesis SameSpot 
software (Nonlinear Dynamics Ltd, Newcastle upon Tyne, UK), and the differences in expression between fully capsulated HCC tissues and HCC tissues with capsular invasion were analyzed statistically by ANOVA; $p<0.05$ was considered significant. After statistical analysis, the gels were re-stained with See Pico ${ }^{\mathrm{TM}}$ (Benebiosis Co., Ltd, Seoul, Republic of Korea), and the selected spots were cut and removed for liquid chromatography-tandem mass spectrometry (LCMS/MS) analysis (15).

In-gel digestion. The See Pico dye was removed from the gel piece by rinsing three times in $60 \%$ methanol, $50 \mathrm{mM}$ ammonium bicarbonate, and $5 \mathrm{mM}$ dithiothreitol (DTT) for $15 \mathrm{~min}$. The sample in the gel piece was reduced twice in 50\% acetonitrile (ACN), 50 $\mathrm{mM}$ ammonium bicarbonate, and $5 \mathrm{mM}$ DTT for $10 \mathrm{~min}$. The gel piece was dehydrated in $100 \% \mathrm{ACN}$ twice for $30 \mathrm{~min}$, and then rehydrated with an in-gel digestion reagent containing $10 \mu \mathrm{g} / \mathrm{ml}$ sequencing-grade-modified trypsin (Promega, Madison, WI, USA) in $30 \% \mathrm{ACN}, 50 \mathrm{mM}$ ammonium bicarbonate, and $5 \mathrm{mM}$ DTT. This procedure for in-gel digestion was performed overnight at $30^{\circ} \mathrm{C}$. The samples were lyophilized overnight with the use of Labconco Lyphlock 1L Model 77400 (Labconco, Kansas, MO, USA). Lyophilized samples were dissolved in $0.1 \%$ formic acid (16).

$L C-M S / M S$. Peptide sequencing of identified protein spots was performed using a QSTAR XL quadrupole time-of-flight mass spectrometer (Applied Biosystems, Foster City, CA, USA). Proteins were identified by an ABSciex DS Sciex Analyst software and MASCOT MS/MS Ions Search engine in a PC Workstation. According to the MASCOT Search engine, the ion score is $-10 * \log (\mathrm{P})$, where $\mathrm{P}$ is the probability that the observed match is a random event. Individual ion scores $>39$ indicate identity or extensive homology $(p<0.05)$. Protein scores are derived from ion scores as a non-probabilistic basis for ranking protein hits.

Western blot analysis. Fifteen $\mu \mathrm{g}$ of the protein samples were used in Western blot analysis. Pre-cast gels (4-20\% gradient polyacrylamide gels; Mini-PROTEAN TGX Gels, Bio-Rad, Hercules, CA, USA) were used for SDS-PAGE. The separated protein bands were transferred onto polyvinylidene difluoride membranes (Immobilon-P; Millipore, Bedford, MA, USA). Blocking was done with Tris-buffered saline with $0.1 \%$ Tween-20 (TBS-T) containing 5\% skimmed milk for $1 \mathrm{~h}$ at room temperature. The primary antibodies used were: rabbit monoclonal antibody against RKIP (PEBP) (\#13006 1:1000, CST, Beverly, MA, USA), rabbit polyclonal antibody against PCK2 (bs-5002R 1:1000, BIOSS Antibodies, Boston, MA, USA), rabbit polyclonal antibody against LAP3 (14612-1-AP 1:1000, Proteintech, Rosemont, IL, USA) and goat polyclonal antibody against actin (1:200, Santa Cruz Biotechnology, Inc., Santa Cruz, CA, USA). Membranes were incubated with each primary antibody overnight at $4^{\circ} \mathrm{C}$, and after washing three times with TBS-T, were further incubated with secondary antibodies conjugated with horseradish peroxidase (Jackson Immuno Research Laboratories Inc., West Grove, PA, USA) for $1 \mathrm{~h}$. Bands of RKIP, LAP3, PCK2 and actin were visualized by an enhanced chemiluminescence system (Clarity Western ECL Substrate; BIO-RAD) and Lumino Graph I (ATTO, Tokyo, Japan). Intensities of bands of RKIP, LAP3, PCK2 and actin were quantified by using the CS Analyzer software (ATTO).

The intensity ratio of RKIP, LAP3 and PCK2 to actin was then calculated in hepatoma tissues with or without encapsulation.

\section{Results}

Figures 2A and B show the 2-DE patterns of hepatocellular carcinoma tissues with and without encapsulation, respectively. More than 600 protein spots were detected. Nine spots (no 207, 219, 212, 615, 595, 252, 217, 191, 160) appear to be up-regulated, and 5 spots (no 233, 302, 293, $511,586)$ appear to be down-regulated in hepatocellular carcinoma tissues without encapsulation vs encapsulated tissues (Table II). These 14 differentially expressed protein spots were picked up and identified by a QSTAR XL quadrupole time-of-flight mass spectrometer. The results of the identification for up-regulated and down-regulated protein spots in the HCC tissues with broken capsule are shown in Tables III and IV, respectively.

From the result of proteomic analysis, the differential expression of phosphatidylethanolamine-binding protein 1 (PEBP1), leucine aminopeptidase 3 (LAP3) and phosphoenolpyruvate carboxykinase mitochondrial (PCK2) was confirmed by using Western blotting (Figure 3). Although the expression of PEBP 1 in HCC tissues with encapsulation tended to be up-regulated compared to HCC tissues with a broken capsule, it was not significant (Figure 4A). On the other hand, the expression of LAP3 and PCK2 was upregulated significantly in HCC tissues with encapsulation compared to HCC tissues with broken capsule (Figure 4B, C).

\section{Discussion}

The results of the present study showed that 14 protein spots were differentially expressed between encapsulated and nonencapsulated HCC tissues as identified by proteomic differential display analysis employing 2-DE and LC-MS/MS. The up-regulated proteins in non-encapsulated HCC tissues were identified as mitochondrial stress-70 protein (HSPA9), heat shock $70 \mathrm{kDa}$ protein 1A (HSPA1A), heat shock cognate $71 \mathrm{kDa}$ protein (HSPA8), mitochondrial $60 \mathrm{kDa}$ heat shock protein (HSPD1), endoplasmic reticulum chaperone $\mathrm{BiP}$ (HSPA5), eukaryotic translation factor 5A-1 (EIF5A), proteasome subunit beta type-9 (PSMB9) and ribosomebinding protein 1 (RRBP1). Heat shock cognate $71 \mathrm{kDa}$ protein was identified from two spots. The down-regulated proteins in non-encapsulated HCC tissues were identified as mitochondrial phosphoenolpyruvate carboxykinase (PCK2), leucine aminopeptidase 3 (LAP3), phenazine biosynthesis-like domain-containing protein and phosphatidylethanolaminebinding protein 1 (PEBP1). Leucine aminopeptidase 3 was identified from two spots.

As up-regulated proteins in HCC tissues without encapsulation, the heat-shock proteins (HSPs) HSPD1, HSPA1A, HSPA5, HSPA8 and HSPA9 were identified. HSPD1 belongs to the HSP $60 \mathrm{kDa}$ family, and HSPA1A, HSPA5, HSPA8 and HSPA9 belong to the HSP $70 \mathrm{kDa}$ family. 
A

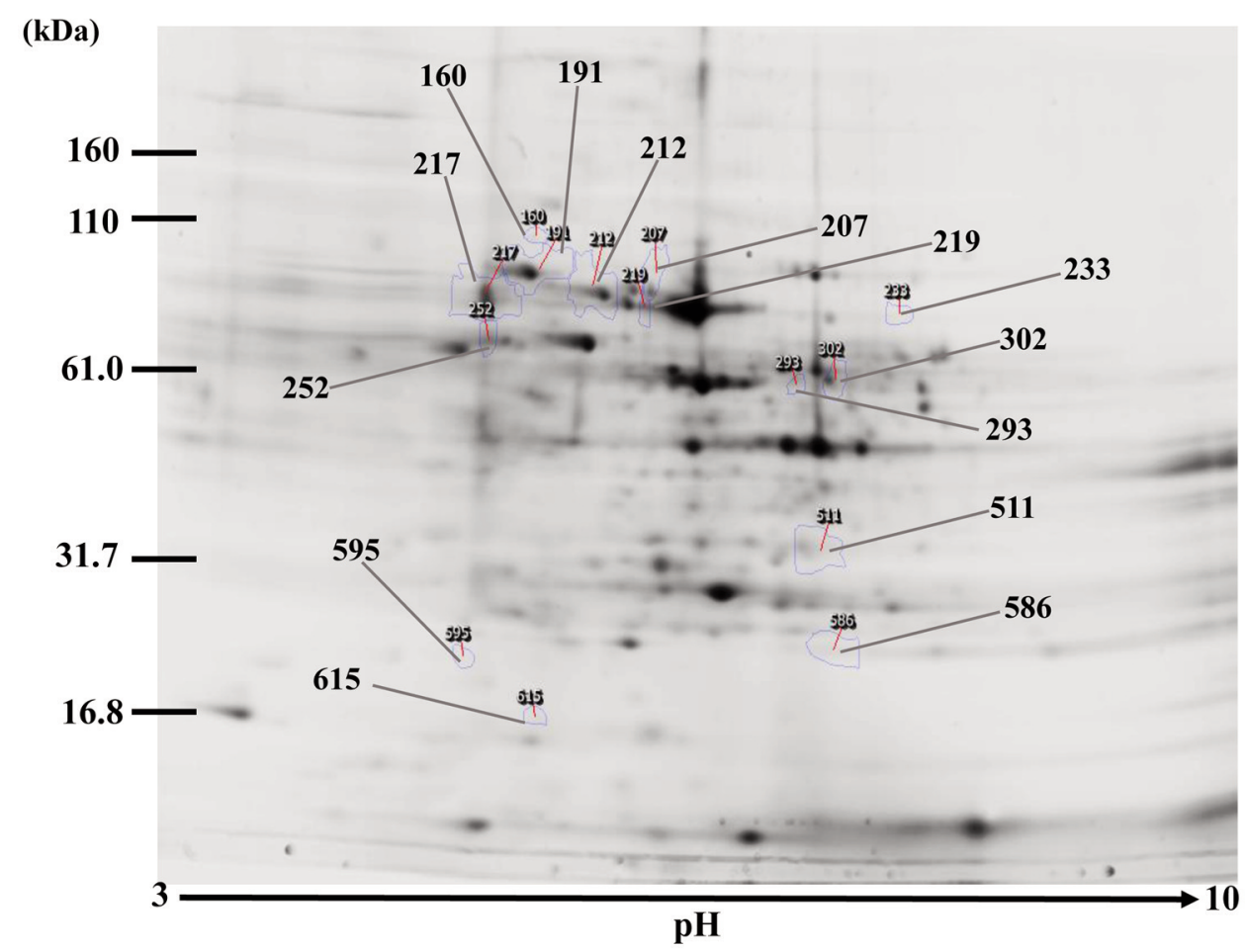

B

(kDa)

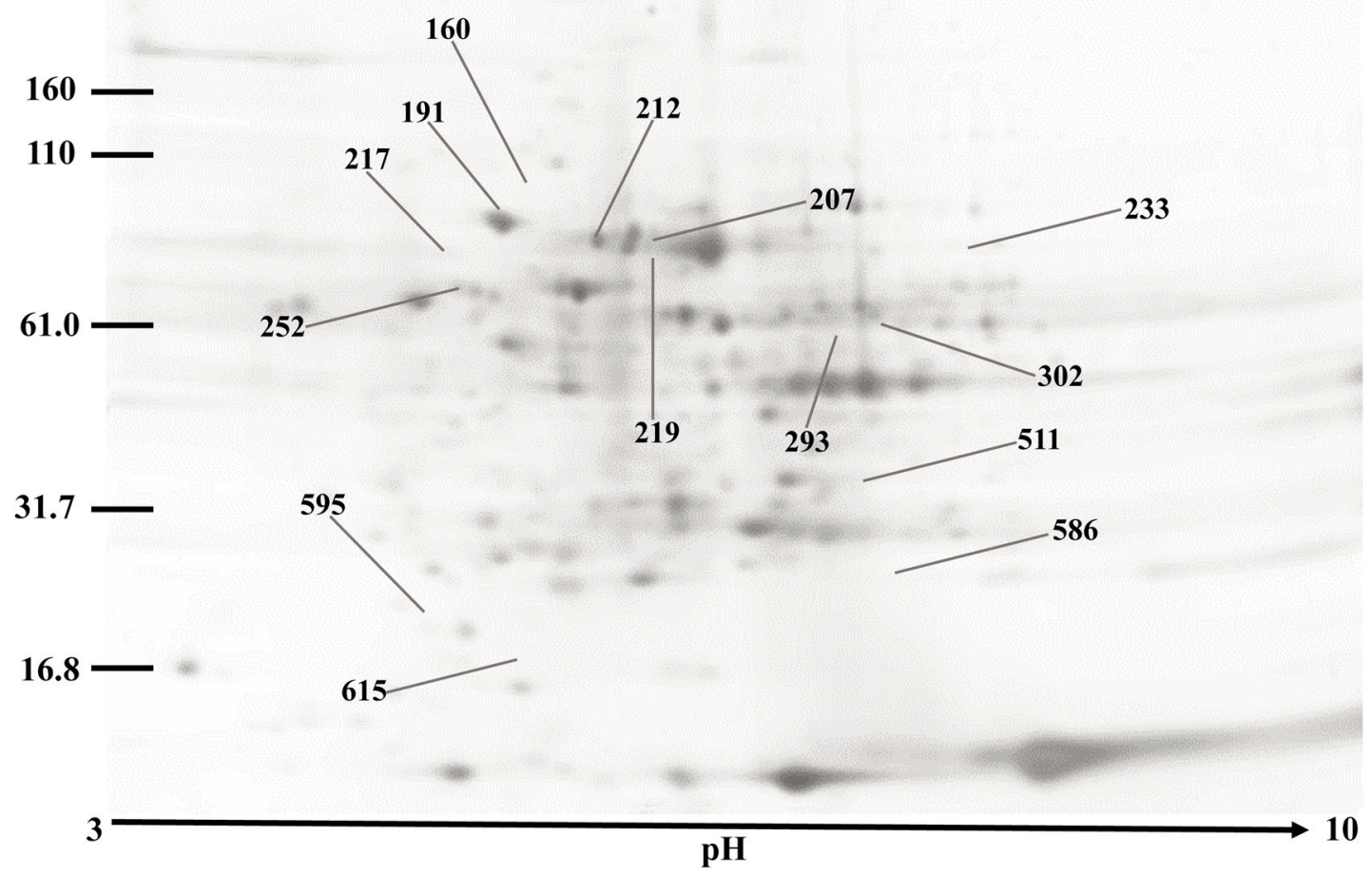

Figure 2. 2-DE gel pattern of (A) HCC tissue without encapsulation, and (B) HCC tissue with encapsulation. Proteins (80 $\mu g$ ) were separated on precast polyacrylamide gel with a linear concentration gradient of 5-20\%. After fixing, the gels were stained with Flamingo Gel Stain ${ }^{T M}$. 
Table I. Summary of all cases of hepatocellular carcinoma.

\begin{tabular}{lccccc}
\hline No. & $\begin{array}{c}\text { Tumor size } \\
(\mathrm{cm})\end{array}$ & Differentiation & $\begin{array}{c}\text { Capsular } \\
\text { invasion }\end{array}$ & $\begin{array}{c}\text { Vascular } \\
\text { invasion }\end{array}$ & Stage \\
\hline 1 & 2.5 & Moderate & - & - & 2 \\
2 & 2.5 & Well & - & - & 2 \\
3 & 1.2 & Moderate & - & - & 1 \\
4 & 2.2 & Moderate & - & - & 2 \\
5 & 2.5 & Moderate & - & - & 2 \\
6 & 13.0 & Poor & + & + & 3 \\
7 & 5.0 & Moderate & + & + & 3 \\
8 & 5.9 & Moderate & + & + & 3 \\
9 & 13.0 & Moderate & + & + & 3 \\
10 & 14.0 & Poor & + & + & 3 \\
\hline
\end{tabular}

HSPs are proteins which mount responses to cellular stress and play roles as molecular chaperones in cells (17). HSPs are classified into the HSP27, HSP40, HSP47, HSP60, HSP70, HSP110 and HSP150 families according to their molecular weight. The role of HSPD1 on the growth of cancer cells is highly controversial (18). HSPA1A and HSPA8 are molecular chaperone which are related to various intracellular process (19). HSPA5 is a molecular chaperone which is also known as binding immunoglobulin protein (BiP) (20). HSPA9, also called GRP75 or mortalin, is located in the mitochondria and inhibits cell division and is implicated in the control of cell proliferation and cellular aging (21). HSP $70 \mathrm{kDa}$ family members have been reported to be related to malignancies. HSPA1A, HSPA8, HSPD1 and HSPD1 are known to function in various intracellular reactions and are up-regulated in cancer cells (22). Some of the HSP $70 \mathrm{kDa}$ members are used as prognostic markers and therapeutic target molecules for cancer treatment (23). Takashima et al. reported that HSP70 kDa family members were up-regulated in $\mathrm{HCV}$-associated $\mathrm{HCC}$ tissues compared to adjacent non-tumoral tissues (24). Jubran et al. reported that determination of HSPA9 and Hsp70 in blood could be a useful additive prognostic tool in guiding clinical management of patients with colorectal cancer (25). Our present study showed up-regulation of HSP70 kDa family proteins in HCC tissues without encapsulation compared to encapsulated HCC tissues. These HSPs appear to be related to the HCC progression process.

EIF5A is a translation factor. eIF5A has two isoforms, eIF5A1 and eIF5A2. eIF5A1 is ubiquitously expressed in most cells. It is essential for cell proliferation and survival (26). In recent years, the role of eIF5A on cancers, diabetes mellitus, HIV-infection etc. have been identified and it has been exploited as a therapeutic target molecule (27). Upregulation of eIF5A1 in various cancer tissues and cells has been reported in multiple studies $(28,29)$. Since eIF5A1
Table II. Protein spots that decreased or increased in HCC tissues without capsule.

\begin{tabular}{lcccc}
\hline$\#$ & $\begin{array}{c}\text { Anova } \\
(\mathrm{p})\end{array}$ & Fold & $\begin{array}{c}\text { Average normalised } \\
\text { volumes }\end{array}$ & $\begin{array}{c}\text { Average normalised } \\
\text { volumes }\end{array}$ \\
\cline { 3 - 5 } & & & With capsulation & Without capsulation \\
\hline 160 & 0.017 & 4.3 & $8.930 \mathrm{e}+004$ & $3.884 \mathrm{e}+005$ \\
207 & 0.019 & 2.0 & $2.396 \mathrm{e}+006$ & $4.825 \mathrm{e}+006$ \\
217 & 0.021 & 2.6 & $4.910 \mathrm{e}+006$ & $1.276 \mathrm{e}+007$ \\
191 & 0.022 & 1.5 & $1.048 \mathrm{e}+007$ & $1.609 \mathrm{e}+007$ \\
302 & 0.024 & 1.5 & $4.063 \mathrm{e}+006$ & $2.665 \mathrm{e}+006$ \\
293 & 0.026 & 2.1 & $1.297 \mathrm{e}+006$ & $6.285 \mathrm{e}+005$ \\
615 & 0.027 & 3.3 & $9.248 \mathrm{e}+004$ & $3.055 \mathrm{e}+005$ \\
252 & 0.031 & 1.7 & $2.260 \mathrm{e}+006$ & $3.832 \mathrm{e}+006$ \\
511 & 0.031 & 1.4 & $4.434 \mathrm{e}+006$ & $3.248 \mathrm{e}+006$ \\
233 & 0.033 & 1.3 & $5.065 \mathrm{e}+005$ & $4.050 \mathrm{e}+005$ \\
212 & 0.039 & 1.4 & $1.492 \mathrm{e}+007$ & $2.119 \mathrm{e}+007$ \\
586 & 0.040 & 2.1 & $2.738 \mathrm{e}+006$ & $1.281 \mathrm{e}+006$ \\
219 & 0.041 & 1.7 & $1.377 \mathrm{e}+006$ & $2.340 \mathrm{e}+006$ \\
595 & 0.048 & 2.4 & $1.082 \mathrm{e}+005$ & $2.572 \mathrm{e}+005$ \\
\hline
\end{tabular}

is essential for cell proliferation and survival, the upregulation of eIF5A1 in HCC tissues without encapsulation seems to be consistent with the characteristics of progressing HCC cells.

PSMB9 is a component of the proteasome which contributes to the complete assembly of the $20 \mathrm{~S}$ proteasome complex (30). Rouette et al. showed that expression of the immunoproteasome including PSMB9 is elevated in most cancer types (31). Even though it is still not clear why the immunoproteasome is upregulated in cancer cells, its function may be increased in highly proliferating cancer cells.

RRBP1 is an endoplasmic reticulum membrane protein (32) which has essential roles for ribosomal function. One function is binding and the other is translocation of nascent proteins across the membrane of the rough endoplasmic reticulum (33). The up-regulation of RRBP1 in many types of cancer cells and tissues has been reported by many research groups (34-36). In line with these, cancer cells may utilize RRBP1 to break encapsulation and proliferate.

In addition, PCK2, LAP3, PEBP1 and PBLD were identified as downregulated proteins in HCC tissue without encapsulation. By means of Western blotting, the significant down-regulation of PCK2 and LAP3 was confirmed.

$\mathrm{Wu}$ et al. reported down-regulation of PBLD in HCC tissues while PBLD inhibited HCC progression via Ras and Rap1 (37). Li et al. found PBLD inhibited HCC cell growth and invasion in vitro and tumor growth in vivo, and they concluded that elevated PBLD expression might reduce HCC cell growth and invasion via inactivation of several tumorigenesis-related signaling pathways (38). 


\section{PEBP}

$21 \mathrm{kDa}$
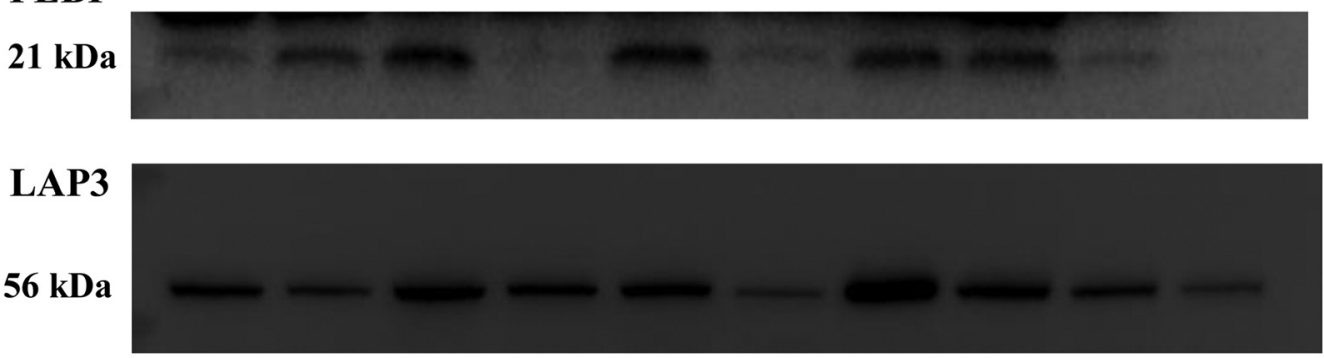

PCK2

$70 \mathrm{kDa}$
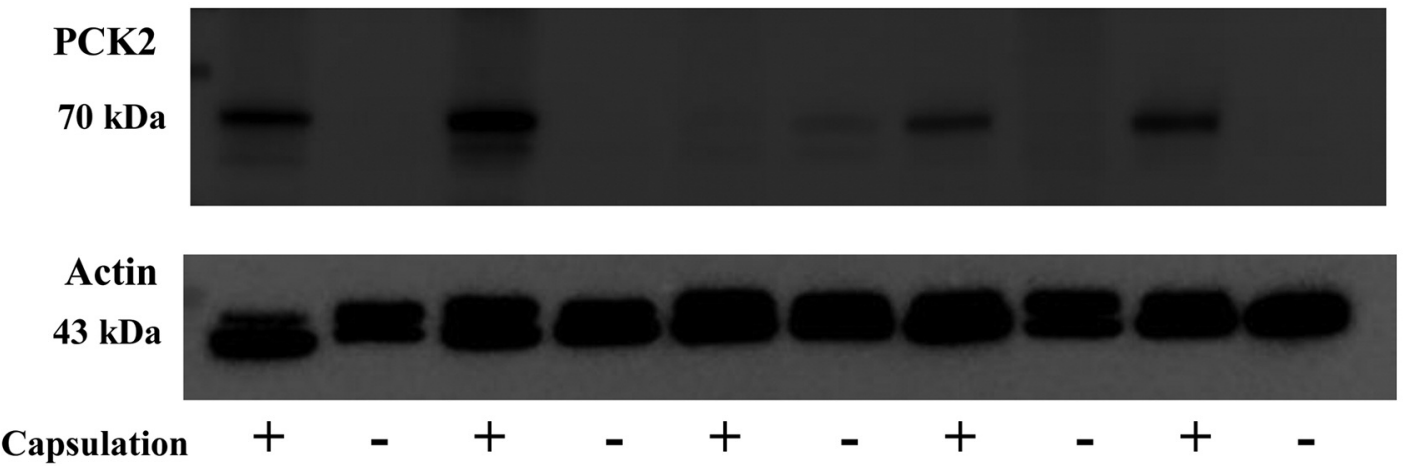

Figure 3. Western blot analysis of PEBP, LAP3, PCK2 and actin in HCC tissues with or without encapsulation. The protein expression of PEBP, $L A P 3$ and PCK2 (bands of 21,56 and $70 \mathrm{kDa}$, respectively) was reduced in HCC tissues with encapsulation compared to HCC tissues without encapsulation.

Table III. Identification of proteins up-regulated in HCC tissues without capsulation.

\begin{tabular}{|c|c|c|c|c|c|c|c|c|}
\hline $\begin{array}{l}\text { Spot } \\
\text { No. }\end{array}$ & Protein name & $\begin{array}{c}\text { Accession } \\
\text { No. }\end{array}$ & $\begin{array}{c}\text { Theoretical } \\
\text { pI }\end{array}$ & $\begin{array}{c}\text { Theoretical } \\
\mathrm{Mr}\end{array}$ & $\begin{array}{l}\text { Distinct } \\
\text { peptides }\end{array}$ & $\begin{array}{c}\text { Sequence } \\
\text { coverage }(\%)\end{array}$ & $\begin{array}{c}\text { MS/MS } \\
\text { search score }\end{array}$ & $\begin{array}{l}\text { Change in } \\
\text { spots (fold) }\end{array}$ \\
\hline 207 & Stress- 70 protein, mitochondrial & P38646 & 5.87 & 73,680 & 17 & 27 & 354 & +2.0 \\
\hline 219 & Heat shock $70 \mathrm{kDa}$ protein $1 \mathrm{~A}$ & P0DMV8 & 5.47 & 70,052 & 11 & 20 & 172 & +1.7 \\
\hline 212 & Heat shock cognate $71 \mathrm{kDa}$ protein & P11142 & 5.37 & 70,898 & 45 & 35 & 612 & +1.4 \\
\hline 615 & Eukaryotic translation factor $5 \mathrm{~A}-1$ & P63241 & 5.07 & 16,832 & 7 & 30 & 111 & +3.3 \\
\hline 595 & Proteasome subunit beta type- 9 & P28065 & 4.89 & 23,264 & 18 & 30 & 232 & +2.4 \\
\hline 252 & $60 \mathrm{kDa}$ heat shock protein, mitochondrial & P10809 & 5.70 & 61,055 & 28 & 56 & 479 & +1.7 \\
\hline 217 & Heat shock cognate $71 \mathrm{kDa}$ protein & P11142 & 5.37 & 70,898 & 3 & 6 & 63 & +2.6 \\
\hline 191 & Endoplasmic reticulum chaperone $\mathrm{BiP}$ & P11021 & 5.07 & 72,333 & 30 & 34 & 522 & +1.5 \\
\hline 160 & Ribosome-binding protein 1 & Q9P2E9 & 5.45 & 108,632 & 11 & 13 & 260 & +4.3 \\
\hline
\end{tabular}

Table IV. Identification of proteins down-regulated in HCC tissues without capsulation.

\begin{tabular}{|c|c|c|c|c|c|c|c|c|}
\hline $\begin{array}{l}\text { Spot } \\
\text { No. }\end{array}$ & Protein name & $\begin{array}{l}\text { Accession } \\
\text { No. }\end{array}$ & $\begin{array}{c}\text { Theoretical } \\
\text { pI }\end{array}$ & $\begin{array}{c}\text { Theoretical } \\
\mathrm{Mr}\end{array}$ & $\begin{array}{l}\text { Distinct } \\
\text { peptides }\end{array}$ & $\begin{array}{c}\text { Sequence } \\
\text { coverage }(\%)\end{array}$ & $\begin{array}{c}\text { MS/MS } \\
\text { search score }\end{array}$ & $\begin{array}{l}\text { Change in } \\
\text { spots (fold) }\end{array}$ \\
\hline 233 & $\begin{array}{l}\text { Phosphoenolpyruvate carboxykinase } \\
\text { mitochondrial }\end{array}$ & Q16822 & 6.63 & 70,699 & 19 & 33 & 251 & -1.3 \\
\hline 302 & Leucine aminopeptidase 3 & P28838 & 8.03 & 56,166 & 37 & 44 & 440 & -1.5 \\
\hline 293 & Leucine aminopeptidase 3 & P28838 & 8.03 & 56,166 & 44 & 57 & 745 & -2.1 \\
\hline 511 & $\begin{array}{l}\text { Phenazine biosynthesis-like } \\
\text { domain-containing protein }\end{array}$ & P30039 & 7.10 & 31,785 & 40 & 76 & 381 & -1.4 \\
\hline 586 & Phosphatidylethanolamine-binding protein 1 & P30086 & 7.01 & 21,057 & 10 & 47 & 176 & -2.1 \\
\hline
\end{tabular}




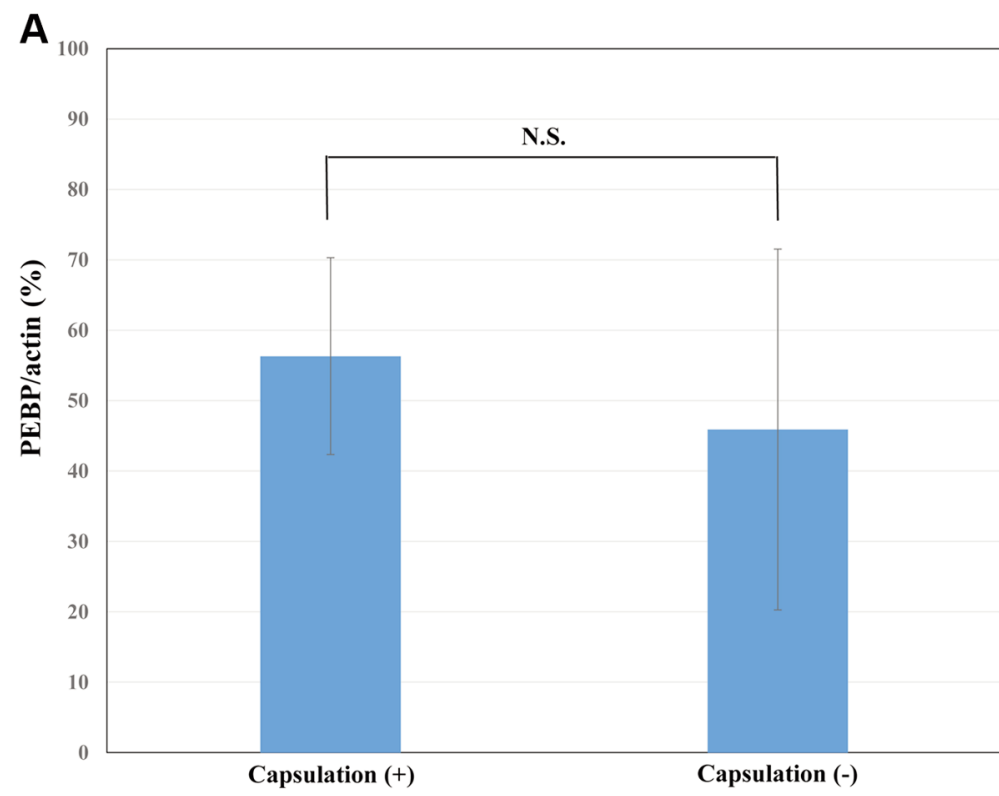

B

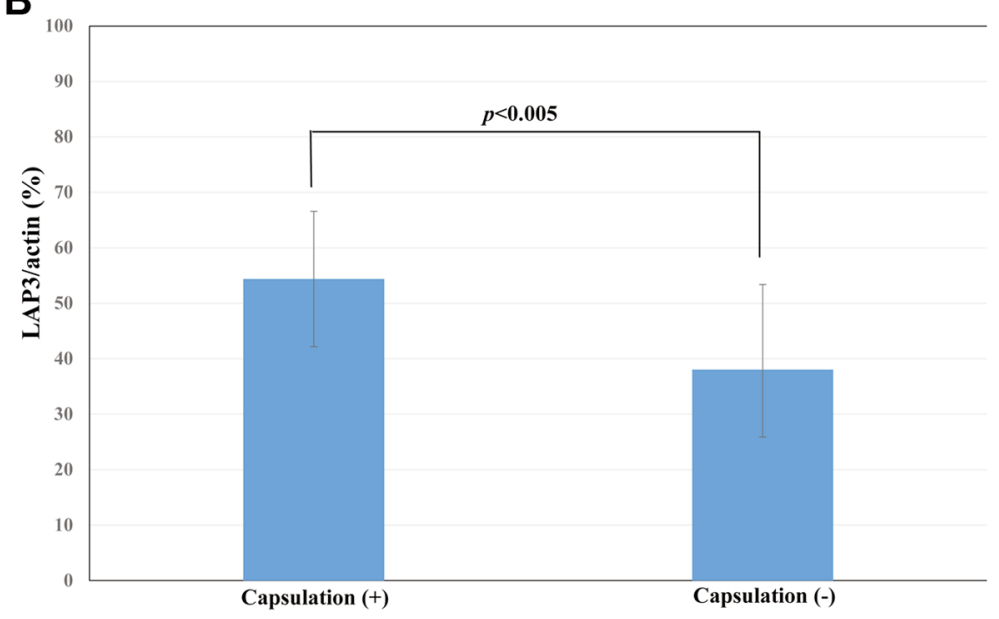

C

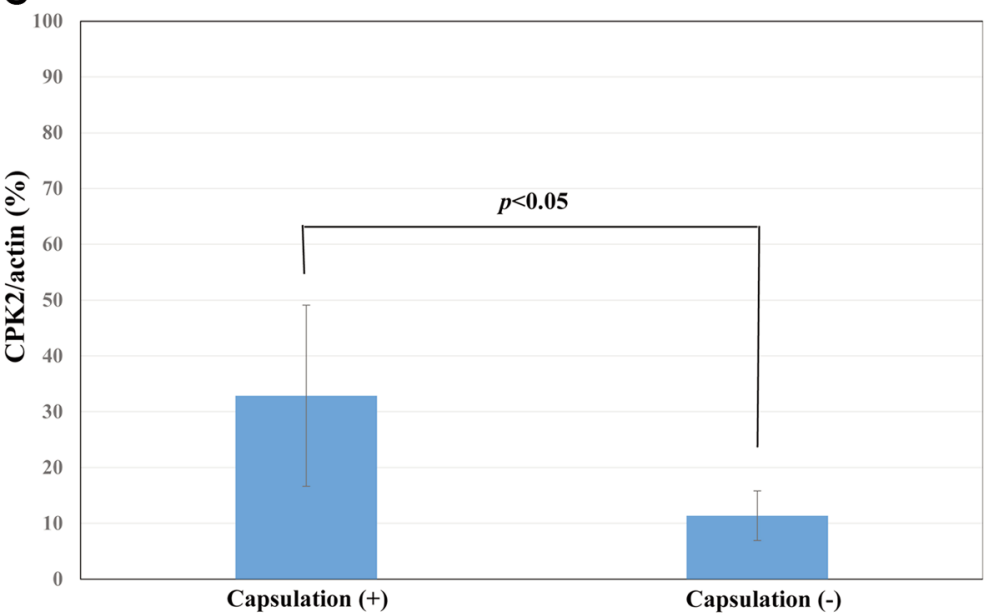

Figure 4. The intensity of (A) PEBP (B) LAP3 bands and (C) PCK2 bands, normalized by actin, in HCC tissues with or without encapsulation. The intensity of LAP3 and PCK2 bands were normalized by actin and were significantly reduced in HCC tissues without encapsulation compared to HCC tissues with encapsulation ( $p<0.05$ and $p<0.005$, respectively by student's t-test). A value of $p<0.05$ was considered statistically significant (n=5). N.S.: not significant. 
PEBP1, also known as Raf kinase inhibitory protein (RKIP), is an inhibitor of the MEK phosphorylation by Raf1. PEBP1 inhibits the Raf-1/MEK/ERK pathway by direct inhibition of Raf-1 and MEK (39), and has anti-metastatic and pro-apoptotic properties in cancer cells (40). Although Western blotting could not show significant down-regulation of PEBP1 in encapsulated HCC tissues compared to HCC tissues without encapsulation, there is a possibility that PEBP1 has a role in the maintenance of encapsulation in HCC tissues.

Significant down-regulation of PCK2 in the HCC tissues without encapsulation was confirmed by Western blotting. PCK2 is a kinase located in the mitochondria. PCK2 phosphorylates oxaloacetic acid and produces phosphoenolpyruvic acid. This phosphoenolpyruvic acid goes through the mitochondrial membrane, and produces glucose (glyconeogenesis) (41). In the central part of cancer tissues, the supply of glucose is not enough for proliferating cancer cells. PCK2 plays an important role in the supply of glucose in cancer cells by using gluconeogenesis. Although some reports showed that the activation of PCK2 increases the proliferative ability of cancer cells (41), the expression of PCK2 was reported to be down-regulated in ovarial cancer cells (42), aflatoxin-induced HCC cells (43), pancreatic cancer cells (44), renal cell carcinoma tissues (45), and osteosarcoma tissues (46). The most interesting report about PCK2-expression is a quantitative proteomic differential display by using isobaric tags for relative and absolute quantification (iTRAQ) for HCC tissues and adjacent non-cancerous tissues. The result showed down-regulation of PCK2 in HCC tissues compared to adjacent non-cancerous tissues. Although they compared PCK2 expression between HCC cancerous and adjacent non-cancerous tissues, our result, where PCK2 was down-regulated in HCC tissues without encapsulation, has a similar result (47).

Significant down-regulation of LAP3 in the HCC tissues without encapsulation was also confirmed by Western blotting. LAP3 is a cell surface aminopeptidase. LAP3 catalyzes the hydrolysis of leucine residues from the protein amino termini (48). It has been reported that LAP3 is related to invasion and metastasis of cancer cells by controlling signal transduction. Fang et al. reported that LAP3 upregulates fascin, which phosphorylates the HSP27-NF- $x \mathrm{~B}$ signalling pathway and promotes the metastatic ability of cancer cells. Furthermore, they showed that LAP3 upregulated matrix metalloproteinase-2 (MMP-2) and MMP-9, and high LAP3 expression was correlated with the grade of malignancy (49). Tian et al. clarified that LAP3 promoted motility and invasiveness of HCC cells (48). Wang et al. reported that vimentin, a mesenchymal marker which strongly relates to EMT, was up-regulated in breast cancer tissues, and LAP3 induced expression of vimentin (50). Although the LAP3-vimentin axis seems to be a promoter of invasion and metastasis, Kajita et al. reported that vimentin accumulated in normal cells specifically at the interface with transformed cells and extruded transformed cells from the epithelium. They called this process cell competition. It is not clear how cell competition starts, but vimentin induced by LAP3 may have an important role in encapsulation of HCC tissues (51).

In conclusion, in HCC tissues with a broken capsule, the protein levels of LAP3 and PCK2 were significantly downregulated. The role of both molecules on the maintenance of encapsulation of HCC tissues is not clear at present. However, further investigation of LAP3 and PCK2 may elucidate their important function for cancer tissue encapsulation, and this could be used as an anti-metastatic strategy to induce encapsulation for cancer tissues and prevent metastasis.

\section{Conflicts of Interest}

The Authors declared no potential conflicts of interest with respect to the research, authorship, and/or publication of this article.

\section{Author's Contributions}

Y.K., K.N., H.N. and M.K. designed the research; Y.K., K.K., T.K. and K.T. performed the experiments; K.S. and H.N. provided the HCC tissues; K.K., Y.K. and B.B. wrote the article.

\section{Acknowledgements}

This work was supported in part by Grants-in-Aid from the Ministry of Education, Science, Sports, and Culture of Japan (no. 17K07218 to Yasuhiro Kuramitsu).

\section{References}

1 Park HA, Brown SR and Kim Y: Cellular mechanisms of circulating tumor cells during breast cancer metastasis. Int J Mol Sci 21(14): 5040, 2020. PMID: 32708855. DOI: 10.3390/ ijms 21145040

2 Layfield HJ, Williams HF, Ravishankar D, Mehmi A, Sonavane M, Salim A, Vaiyapuri R, Lakshminarayanan K, Vallance TM, Bicknell AB, Trim SA, Patel K and Vaiyapuri S: Repurposing cancer drugs batimastat and marimastat to inhibit the activity of a group I metalloprotease from the venom of the western diamondback rattlesnake, Crotalus atrox. Toxins (Basel) 12(5): 309, 2020. PMID: 32397419. DOI: 10.3390/toxins12050309

3 Heath EI, Burtness BA, Kleinberg L, Salem RR, Yang SC, Heitmiller RF, Canto MI, Knisely JP, Topazian M, Montgomery E, Tsottles N, Pithavala Y, Rohmiller B, Collier M and Forastiere AA: Phase II, parallel-design study of preoperative combined modality therapy and the matrix metalloprotease (mmp) inhibitor prinomastat in patients with esophageal adenocarcinoma. Invest New Drugs 24(2): 135-140, 2006. PMID: 16502351. DOI: 10.1007/s10637-006-5934-5

4 Heath EI and Grochow LB: Clinical potential of matrix metalloprotease inhibitors in cancer therapy. Drugs 59(5): 10431055, 2000. PMID: 10852638. DOI: 10.2165/00003495200059050-00002 
5 Brown PD: Ongoing trials with matrix metalloproteinase inhibitors. Expert Opin Investig Drugs 9(9): 2167-2177, 2000. PMID: 11060801. DOI: 10.1517/13543784.9.9.2167

6 Abdollahi A, Lipson KE, Han X, Krempien R, Trinh T, Weber KJ, Hahnfeldt P, Hlatky L, Debus J, Howlett AR and Huber PE: SU5416 and SU6668 attenuate the angiogenic effects of radiation-induced tumor cell growth factor production and amplify the direct anti-endothelial action of radiation in vitro. Cancer Res 63(13): 3755-3763, 2003. PMID: 12839971.

7 Anderson RL, Balasas T, Callaghan J, Coombes RC, Evans J, Hall JA, Kinrade S, Jones D, Jones PS, Jones R, Marshall JF, Panico MB, Shaw JA, Steeg PS, Sullivan M, Tong W, Westwell AD, Ritchie JWA and Cancer Research UK and Cancer Therapeutics CRC Australia Metastasis Working Group: A framework for the development of effective anti-metastatic agents. Nat Rev Clin Oncol 16(3): 185-204, 2019. PMID: 30514977. DOI: 10.1038/s41571-018-0134-8

8 Lim JH, Choi D, Park CK, Lee WJ and Lim HK: Encapsulated hepatocellular carcinoma: CT-pathologic correlations. Eur Radiol 16(10): 2326-2333, 2006. PMID: 16547706. DOI: 10.1007/ s00330-006-0203-8

$9 \mathrm{Ng}$ IO, Lai EC, Ng MM and Fan ST: Tumor encapsulation in hepatocellular carcinoma. A pathologic study of 189 cases. Cancer 70(1): 45-49, 1992. PMID: 1318778. DOI: 10.1002/ 1097-0142(19920701)70:1<45::aid-cncr2820700108>3.0.co;2-7

$10 \mathrm{Wu}$ TH, Yu MC, Chen TC, Lee CF, Chan KM, Wu TJ, Chou HS, Lee WC and Chen MF: Encapsulation is a significant prognostic factor for better outcome in large hepatocellular carcinoma. J Surg Oncol 105(1): 85-90, 2012. PMID: 22161900. DOI: $10.1002 /$ jso. 22060

11 Ooi LP, Crawford DH, Gotley DC, Clouston AD, Strong RW, Gobe GC, Halliday JW, Bridle KR and Ramm GA: Evidence that "myofibroblast-like" cells are the cellular source of capsular collagen in hepatocellular carcinoma. J Hepatol 26(4): 798-807, 1997. PMID: 9126792 . DOI: $10.1016 / \mathrm{s} 0168-8278(97) 80245-0$

12 Bridle KR, Crawford DH, Powell LW and Ramm GA: Role of myofibroblasts in tumour encapsulation of hepatocellular carcinoma in haemochromatosis. Liver 21(2): 96-104, 2001. PMID: 11318978. DOI: 10.1034/j.1600-0676.2001.021002096.x

13 Kuramitsu Y, Hayashi E, Okada F, Tanaka T, Zhang X, Ueyama $\mathrm{Y}$ and Nakamura K: Proteomic analysis for nuclear proteins related to tumour malignant progression: A comparative proteomic study between malignant progressive cells and regressive cells. Anticancer Res 30(6): 2093-2099, 2010. PMID: 20651356.

14 Kuramitsu Y, Miyamoto H, Tanaka T, Zhang X, Fujimoto M, Ueda K, Tanaka T, Hamano K and Nakamura K: Proteomic differential display analysis identified upregulated astrocytic phosphoprotein PEA-15 in human malignant pleural mesothelioma cell lines. Proteomics 9(22): 5078-5089, 2009. PMID: 19771552. DOI: 10.1002/pmic.200800284

15 Kuramitsu Y, Hayashi E, Okada F, Zhang X, Tanaka T, Ueyama $\mathrm{Y}$ and Nakamura K: Staining with highly sensitive coomassie brilliant blue SeePico ${ }^{\mathrm{TM}}$ stain after Flamingo ${ }^{\mathrm{TM}}$ fluorescent gel stain is useful for cancer proteomic analysis by means of twodimensional gel electrophoresis. Anticancer Res 30(10): 40014005, 2010. PMID: 21036714.

16 Baron B, Fujioka T, Kitagawa T, Maehara S, Maehara Y, Nakamura K and Kuramitsu Y: Comparative proteomic analysis of two stress-management strategies in pancreatic cancer. Cancer Genomics Proteomics 12(2): 83-87, 2015. PMID: 25770192.
17 Wu J, Liu T, Rios Z, Mei Q, Lin X and Cao S: Heat shock proteins and cancer. Trends Pharmacol Sci 38(3): 226-256, 2017. PMID: 28012700. DOI: 10.1016/j.tips.2016.11.009

18 Hoter A, Rizk S and Naim HY: Heat shock protein 60 in hepatocellular carcinoma: Insights and perspectives. Front Mol Biosci 7: 60, 2020. PMID: 32351972. DOI: 10.3389/fmolb. 2020.00060

19 Radons J: The human HSP70 family of chaperones: where do we stand? Cell Stress Chaperones 21(3): 379-404, 2016. PMID: 26865365. DOI: $10.1007 / \mathrm{s} 12192-016-0676-6$

20 Wang J, Lee J, Liem D and Ping P: HSPA5 Gene encoding Hsp70 chaperone BiP in the endoplasmic reticulum. Gene 618: 14-23, 2017. PMID: 28286085. DOI: 10.1016/j.gene.2017.03.005

21 Domanico SZ, DeNagel DC, Dahlseid JN, Green JM and Pierce SK: Cloning of the gene encoding peptide-binding protein 74 shows that it is a new member of the heat shock protein 70 family. Mol Cell Biol 13(6): 3598-3610, 1993. PMID: 7684501. DOI: $10.1128 / \mathrm{mcb} .13 .6 .3598$

22 Chatterjee S and Burns TF: Targeting heat shock proteins in cancer: A promising therapeutic approach. Int J Mol Sci 18(9): 1978, 2017. PMID: 28914774. DOI: 10.3390/ijms 18091978

23 Narayanankutty V, Narayanankutty A and Nair A: Heat Shock Proteins (HSPs): A novel target for cancer metastasis prevention. Curr Drug Targets 20(7): 727-737, 2019. PMID: 30526455. DOI: $10.2174 / 1389450120666181211111815$

24 Takashima M, Kuramitsu Y, Yokoyama Y, Iizuka N, Toda T, Sakaida I, Okita K, Oka M and Nakamura K: Proteomic profiling of heat shock protein 70 family members as biomarkers for hepatitis C virus-related hepatocellular carcinoma. Proteomics 3(12): 2487-2493, 2003. PMID: 14673798. DOI: 10.1002/pmic.200300621

25 Jubran R, Kocsis J, Garam N, Maláti É, Gombos T, Barabás L, Gráf L, Prohászka Z and Fishelson Z: Circulating mitochondrial stress 70 protein/mortalin and cytosolic Hsp70 in blood: Risk indicators in colorectal cancer. Int J Cancer 141(11): 2329-2335, 2017. PMID: 28791678. DOI: 10.1002/ijc.30918

26 Mathews MB and Hershey JW: The translation factor eIF5A and human cancer. Biochim Biophys Acta 1849(7): 836-844, 2015. PMID: 25979826. DOI: 10.1016/j.bbagrm.2015.05.002

27 Kaiser A: Translational control of eIF5A in various diseases. Amino Acids 42(2-3): 679-684, 2012. PMID: 21818564. DOI: 10.1007/s00726-011-1042-8

28 Mémin E, Hoque M, Jain MR, Heller DS, Li H, Cracchiolo B, Hanauske-Abel HM, Pe'ery T and Mathews MB: Blocking eIF5A modification in cervical cancer cells alters the expression of cancer-related genes and suppresses cell proliferation. Cancer Res 74(2): 552-562, 2014. PMID: 24220243. DOI: 10.1158/0008-5472.CAN-13-0474

29 Lam F, Jankova L, Dent OF, Molloy MP, Kwun SY, Clarke C, Chapuis P, Robertson G, Beale P, Clarke S, Bokey EL and Chan $\mathrm{C}$ : Identification of distinctive protein expression patterns in colorectal adenoma. Proteomics Clin Appl 4(1): 60-70, 2010. PMID: 21137016. DOI: 10.1002/prca.200900084

30 Hayashi T, Kawano M, Sano K, Ichimura T, Gur G, Yaish P, Zharhary D, Kanai Y, Tonegawa S, Shiozawa T, Yaegashi N and Konishi I: A novel diagnostic biomarker for human uterine leiomyosarcoma: PSMB9/ß1i. Chin Clin Oncol 6(2): 22, 2017. PMID: 28482675. DOI: 10.21037/cco.2017.04.03

31 Rouette A, Trofimov A, Haberl D, Boucher G, Lavallée VP, D’Angelo G, Hébert J, Sauvageau G, Lemieux S and Perreault 
C: Expression of immunoproteasome genes is regulated by cellintrinsic and -extrinsic factors in human cancers. Sci Rep 6: 34019, 2016. PMID: 27659694. DOI: 10.1038/srep34019

32 Benyamini P, Webster P and Meyer DI: Knockdown of p180 eliminates the terminal differentiation of a secretory cell line. Mol Biol Cell 20(2): 732-744, 2009. PMID: 19037105. DOI: 10.1091/mbc.e08-07-0682

33 Savitz AJ and Meyer DI: $180-\mathrm{kD}$ ribosome receptor is essential for both ribosome binding and protein translocation. J Cell Biol 120(4): 853-863, 1993. PMID: 8381785. DOI: $10.1083 / \mathrm{jcb}$. 120.4 .853

34 Liu S, Lin M, Ji H, Ding J, Zhu J, Ma R and Meng F: RRBP1 overexpression is associated with progression and prognosis in endometrial endometrioid adenocarcinoma. Diagn Pathol 14(1): 7, 2019. PMID: 30684972. DOI: 10.1186/s13000-019-0784-6

35 Liang X, Sun S, Zhang X, Wu H, Tao W, Liu T, Wei W, Geng J and Pang D: Expression of ribosome-binding protein 1 correlates with shorter survival in Her-2 positive breast cancer. Cancer Sci 106(6): 740-746, 2015. PMID: 25845758. DOI: 10.1111/ cas. 12666

36 Ma J, Ren S, Ding J, Liu S, Zhu J, Ma R and Meng F: Expression of RRBP1 in epithelial ovarian cancer and its clinical significance. Biosci Rep 39(7): 2019. PMID: 31285390. DOI: 10.1042/BSR20190656

37 Wu J, Niu Q, Yuan J, Xu X and Cao L: Novel compound cedrelone inhibits hepatocellular carcinoma progression via PBLD and Ras/Rap1. Exp Ther Med 18(6): 4209-4220, 2019. PMID: 31777531. DOI: 10.3892/etm.2019.8080

38 Li A, Yan Q, Zhao X, Zhong J, Yang H, Feng Z, Du Y, Wang Y, Wang Z, Wang H, Zhou Y, Liu S and Nie Y: Decreased expression of PBLD correlates with poor prognosis and functions as a tumor suppressor in human hepatocellular carcinoma. Oncotarget 7(1): 524-537, 2016. PMID: 26594798. DOI: $10.18632 /$ oncotarget.6358

39 Serre L, Pereira de Jesus K, Zelwer C, Bureaud N, Schoentgen $\mathrm{F}$ and Bénédetti H: Crystal structures of YBHB and YBCL from Escherichia coli, two bacterial homologues to a Raf kinase inhibitor protein. J Mol Biol 310(3): 617-634, 2001. PMID: 11439028. DOI: $10.1006 /$ jmbi.2001.4784

40 Yeung K, Janosch P, McFerran B, Rose DW, Mischak H, Sedivy JM and Kolch W: Mechanism of suppression of the Raf/ MEK/extracellular signal-regulated kinase pathway by the raf kinase inhibitor protein. Mol Cell Biol 20(9): 3079-3085, 2000. PMID: 10757792. DOI: 10.1128/mcb.20.9.3079-3085.2000

41 Montal ED, Dewi R, Bhalla K, Ou L, Hwang BJ, Ropell AE, Gordon C, Liu WJ, DeBerardinis RJ, Sudderth J, Twaddel W, Boros LG, Shroyer KR, Duraisamy S, Drapkin R, Powers RS, Rohde JM, Boxer MB, Wong KK and Girnun GD: PEPCK coordinates the regulation of central carbon metabolism to promote cancer cell growth. Mol Cell 60(4): 571-583, 2015. PMID: 26481663. DOI: 10.1016/j.molcel.2015.09.025

42 Peng X, Yu M and Chen J: Transcriptome sequencing identifies genes associated with invasion of ovarian cancer. J Int Med Res 48(9): 300060520950912, 2020. PMID: 32878513. DOI: $10.1177 / 0300060520950912$
43 Cai P, Zheng H, She J, Feng N, Zou H, Gu J, Yuan Y, Liu X, Liu $\mathrm{Z}$ and Bian J: Molecular mechanism of aflatoxin-induced hepatocellular carcinoma derived from a bioinformatics analysis. Toxins (Basel) 12(3): 203, 2020. PMID: 32210020. DOI: 10.3390/toxins12030203

44 Wang L, Liu HL, Li Y and Yuan P: Proteomic analysis of pancreatic intraepithelial neoplasia and pancreatic carcinoma in rat models. World J Gastroenterol 17(11): 1434-1441, 2011. PMID: 21472101. DOI: 10.3748/wjg.v17.i11.1434

45 Xiong Z, Yuan C, Shi J, Xiong W, Huang Y, Xiao W, Yang H, Chen $\mathrm{K}$ and Zhang $\mathrm{X}$ : Restoring the epigenetically silenced PCK2 suppresses renal cell carcinoma progression and increases sensitivity to sunitinib by promoting endoplasmic reticulum stress. Theranostics 10(25): 11444-11461, 2020. PMID: 33052225. DOI: $10.7150 /$ thno.48469

46 Zhang Y, Zhao H, Xu W, Jiang D, Huang L and Li L: High expression of $P Q B P 1$ and low expression of $P C K 2$ are associated with metastasis and recurrence of osteosarcoma and unfavorable survival outcomes of the patients. J Cancer 10(9): 2091-2101, 2019. PMID: 31205570. DOI: 10.7150/jca.28480

47 Chaerkady R, Harsha HC, Nalli A, Gucek M, Vivekanandan P, Akhtar J, Cole RN, Simmers J, Schulick RD, Singh S, Torbenson M, Pandey A and Thuluvath PJ: A quantitative proteomic approach for identification of potential biomarkers in hepatocellular carcinoma. J Proteome Res 7(10): 4289-4298, 2008. PMID: 18715028. DOI: 10.1021/pr800197z

48 Tian SY, Chen SH, Shao BF, Cai HY, Zhou Y, Zhou YL and Xu AB: Expression of leucine aminopeptidase 3 (LAP3) correlates with prognosis and malignant development of human hepatocellular carcinoma (HCC). Int J Clin Exp Pathol 7(7): 3752-3762, 2014. PMID: 25120751.

49 Fang C, Zhang J, Yang H, Peng L, Wang K, Wang Y, Zhao X, Liu H, Dou C, Shi L, Zhao C, Liang S, Li D and Wang X: Leucine aminopeptidase 3 promotes migration and invasion of breast cancer cells through upregulation of fascin and matrix metalloproteinases-2/9 expression. J Cell Biochem 120(3): 36113620, 2019. PMID: 30417585. DOI: 10.1002/jcb.27638

50 Wang X, Ji S, Ma Y, Xing X, Zhou Y, Xu X, Song J, Wang S, Jiang W, Wang $X$, Yan $F$ and Fang C: Vimentin plays an important role in the promotion of breast cancer cell migration and invasion by leucine aminopeptidase 3. Cytotechnology 72(5): 639-647, 2020. PMID: 32572729. DOI: 10.1007/s10616020-00402-x

51 Kajita M, Sugimura K, Ohoka A, Burden J, Suganuma H, Ikegawa M, Shimada T, Kitamura T, Shindoh M, Ishikawa S, Yamamoto S, Saitoh S, Yako Y, Takahashi R, Okajima T, Kikuta J, Maijima Y, Ishii M, Tada M and Fujita Y: Filamin acts as a key regulator in epithelial defence against transformed cells. Nat Commun 5: 4428, 2014. PMID: 25079702. DOI: 10.1038/ncomms5428

Received February 16, 2021

Revised March 5, 2021

Accepted March 8, 2021 